\title{
Prader-Willi syndrome: an update on obesity and endocrine problems
}

\author{
Su Jin Kim ${ }^{1,2}$, \\ Sung Yoon $\mathrm{Cho}^{3}$, \\ Dong-Kyu Jin ${ }^{3}$
}

'Department of Pediatrics, Inha University Hospital, Inha University College of Medicine, Incheon, Korea ${ }^{2}$ Northwest Gyeonggi Regional Center for Rare Disease, Inha University Hospital, Incheon, Korea

${ }^{3}$ Department of Pediatrics, Samsung Medical Center, Sungkyunkwan University School of Medicine, Seoul, Korea
Received: 16 August, 2021

Accepted: 30 August, 2021

\author{
Address for correspondence: \\ Dong-Kyu Jin \\ Department of Pediatrics, Samsung \\ Medical Center, Sungkyunkwan \\ University School of Medicine, \\ 81 Irwon-ro, Gangnam-gu, Seoul, \\ 06351, Korea \\ Email:jindk@samsung.com \\ https://orcid.org/0000-0003-4162- \\ 2706
}

Prader-Willi syndrome (PWS) is a rare complex genetic disorder that results from a lack of expression of the paternally inherited chromosome 15q11-q13. PWS is characterized by hypotonia and feeding difficulty in early infancy and development of morbid obesity aggravated by uncontrolled hyperphagia after childhood and adolescent. Dysmorphic facial features, delayed motor and language development, various degrees of cognitive impairment, and behavioral problems are common in PWS. Without early, intensive nutritional therapy along with behavioral modification, PWS patients develop severe obesity associated with type 2 diabetes, obstructive sleep apnea, right-side heart failure, and other obesity-related metabolic complications. Hypothalamic dysfunction in PWS can lead to several endocrine disorders, including short stature with growth hormone deficiency, hypothyroidism, central adrenal insufficiency, and hypogonadism. In this review, we discuss the natural history of PWS and the mechanisms of hyperphagia and obesity. We also provide an update on obesity treatments and recommendations for screening and monitoring of various endocrine problems that can occur in PWS.

Keywords: Prader-Willi syndrome, obesity, endocrine system disease, hypothalamic dysfunction

\section{Highlights}

Understanding the mechanisms that lead to hyperphagia and early nutritional intervention with behavioral modifications are important for PWS management. Pediatric endocrinologists should be aware of the recommendations for endocrine problems that can occur in PWS.

\section{Introduction}

Prader-Willi syndrome (PWS, OMIM \#176270) is a complex genetic disorder caused by lack of expression of the paternally inherited chromosome 15q11-q13. ${ }^{1)}$ There are three major molecular classes in PWS: paternal deletion of the chromosome 15q11-q13 region (the most common type of PWS, 65\%-75\%), maternal uniparental disomy of chromosome 15 (20\%$30 \%$ ), and imprinting defects caused by epimutations or microdeletions in the imprinting center of the chromosome $15 \mathrm{q} 11-\mathrm{q} 13$ region $(1 \%-3 \%){ }^{2-4)}$ In addition to these major classes, there are very rare balanced translocations involving the PWS region on chromosome 15q11-q13 (0.1\%). ${ }^{5)}$ Previous epidemiologic studies have estimated the incidence of PWS from 1 in 10,000 to 1 in 30,000 live births. ${ }^{6-8)}$ Clinically, PWS is characterized by hypotonia and feeding difficulty in early infancy, and development of hyperphagia exacerbated by impaired satiety from late infancy or childhood is characteristic of PWS.

Without aggressive control of excessive eating behaviors, PWS patients develop severe obesity associated with type 2 diabetes mellitus (T2DM), obstructive sleep apnea, right-side heart failure, and other obesity-related metabolic complications later in life. Dysmorphic 
facial features, delayed development of motor and language skills, various degrees of cognitive impairment, and behavioral problems are common in patients with PWS. Hypothalamic dysfunction can lead to hyperphagia, obesity, and several endocrine disorders, including short stature with growth hormone deficiency (GHD), hypothyroidism, central adrenal insufficiency (CAI), and hypogonadism in PWS patients. ${ }^{910)}$ This review aims to provide an update of the obesity caused by hyperphagia and the endocrine problems present in PWS.

\section{Natural history of PWS}

The natural course of PWS has several nutritional phases with gradual and complex progression. ${ }^{11)}$ Fig. 1 summarizes the nutritional stages of PWS. During Phase 0, prenatal features of PWS include decreased fetal activity, polyhydramnios, breech presentation, small for gestational age, and lower birth weight than siblings. ${ }^{12)}$ In phase 1 (at birth), hypotonia is noted. During phase 1a (0-9 months), poor sucking and feeding difficulties with/without failure to thrive develop. In phase $1 \mathrm{~b}$ (9-24 months), the infant grows steadily along a disease-specific growth chart. ${ }^{13,14)}$ Phase 2 involves the transition from anorexia to excessive weight gain. In phase $2 \mathrm{a}(2-4.5$ years), weight gain without a significant change in appetite occurs. During phase $2 \mathrm{~b}$ (4.5-8 years), appetite tends to increase along with interest in food. Phase 3 ( 8 years-adult) onward is marked by hyperphagia with uncontrolled appetite accompanied by a lack of satiety and food-seeking behavior.

Some but not most adults move on to phase 4, where they no longer have an increased appetite. The precise mechanism by which the nutritional phases progress is unknown. As these stages progress, various behavioral and endocrine problems arise. Comorbidities accompany these patients throughout their lives. Management of PWS requires a team approach, including a neonatologist, medical geneticist, pediatric endocrinologist, endocrinologist/diabetologist, psychologist, orthopedist, specialized dietitian, speech therapist, physical therapist, psychotherapist, social worker, etc. ${ }^{1,15-17)}$

Despite recent improvements in multidisciplinary care of patients with PWS, its morbidity and mortality rates increase with age. ${ }^{18,19)}$ According to previous observational studies, the mean age of death in patients with PWS was $29.5 \pm 16$ years (range, 1 month-67 years), and respiratory problems (including respiratory failure and pulmonary infection) were the most common causes of death at all ages. The other causes of death in PWS were cardiovascular disease, gastrointestinal causes, infection, choking events, and accidents. ${ }^{19-21)}$

\section{Hyperphagia and obesity in PWS}

\section{Mechanism of hyperphagia and obesity in PWS}

Understanding the pathophysiology of hyperphagia and obesity in PWS is very important for the care of patients with PWS. Although research has investigated the mechanisms of hyperphagia and obesity in PWS, much remains unclear. Hypothalamic dysfunction might affect appetite control, energy expenditure, and orexigenic/anorexigenic hormone regulation, leading to hyperphagia and obesity in PWS. ${ }^{22-24)}$

Studies using functional magnetic resonance imaging (fMRI) data showed hyperactivation in response to appealing food or hypoactivation in response to disliked food in the hypothalamus of PWS patients compared with controls. ${ }^{25-27)}$ These findings suggest that dysfunction in the subcortical reward circuitry and the cortical inhibitory regions associated with appetite and behavioral control in the hypothalamus is involved in development and progression of hyperphagia and obesity in PWS.

Ghrelin is a gut hormone secreted by the gastric mucosa. Acylated ghrelin $(\mathrm{AG})$ is a representative orexigenic hormone

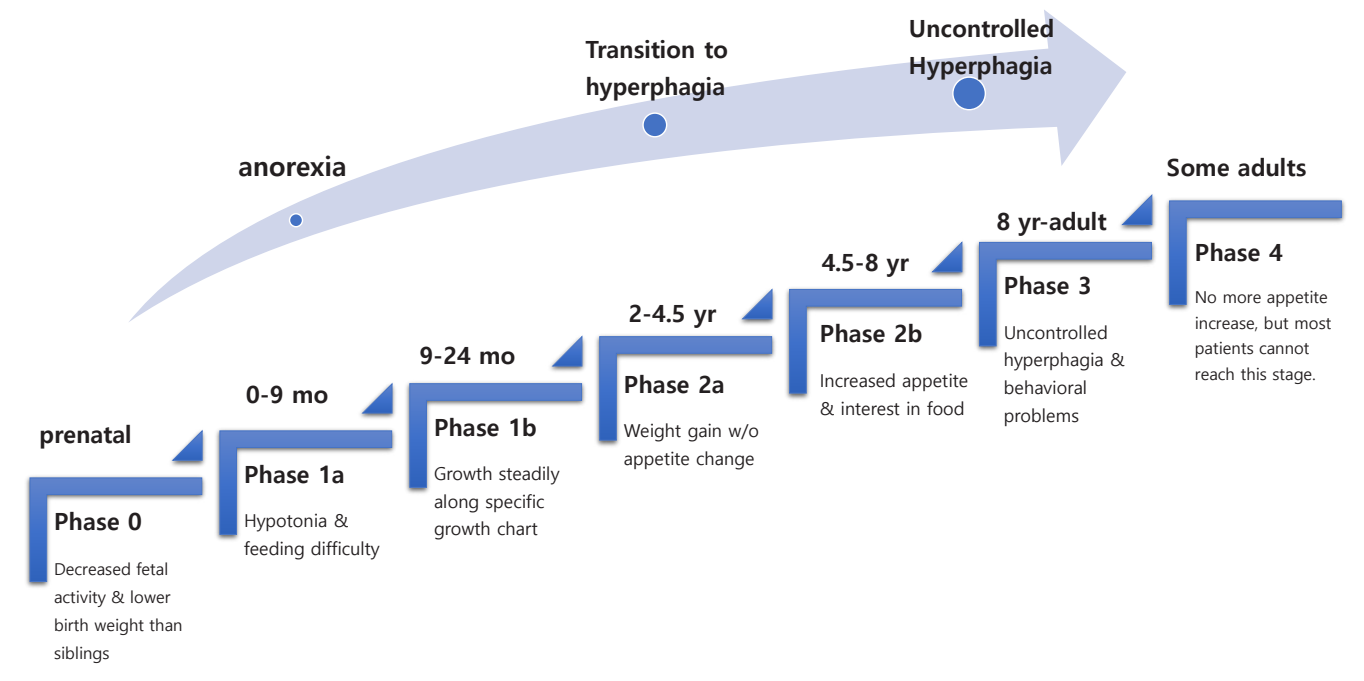

Fig. 1. The nutritional stages of Prader-Willi syndrome. 
that is activated by binding to the growth hormone secretagogue receptor la (GHSRla). Unacylated ghrelin (UAG) is present in the circulation and has the opposite effect of AG. In PWS, high serum level of total ghrelin (especially AG) was persistent even after food intake, which can cause a delay in the sense of fullness and lead to hyperphagia and obesity. Conversely, high UAG level was observed in PWS infants, which might be associated with anorexia in the early nutritional phase (phase 1) before the onset of hyperphagia. ${ }^{28-31)}$

Oxytocin, a neuropeptide produced in the paraventricular nucleus (PVN) of the hypothalamus, is involved in the homeostatic control of satiety, energy balance, social interaction, and obsessive-compulsive behaviors as well as uterine contractions and lactation promotion. ${ }^{32)}$ Previous studies have revealed a reduced volume of PVN in the hypothalamus and higher serum and cerebrospinal fluid levels of oxytocin in PWS patients compared with controls. ${ }^{33-35)}$ Recently, it has been suggested that the GHSR1a receptor and the oxytocin receptor heterocomplex interact to alter the signaling pathways that regulate appetite and satiety. ${ }^{36,37)}$ Several clinical trials that use these analogs to control appetite in PWS patients are being conducted, but no consistent conclusion has been achieved. ${ }^{38-40)}$ The roles of ghrelin and oxytocin in appetite regulation and obesity in PWS remain unclear.

Other studies that have examined the roles of several anorexigenic or adipose-derived hormones related to the pathophysiology of obesity have been reported with mixed results in PWS patients (Table 1). ${ }^{41-49)}$ The factors that regulate appetite and obesity are complex, and substances other than hormones influence the interactions of these various factors. Therefore, further studies are needed.

Recent studies using genome-wide transcriptomic analysis of the PWS hypothalamus are emerging to explain the mechanisms behind hyperphagia and obesity in PWS. ${ }^{50)}$ Bochukova et al. suggested that the hypothalamus in PWS patients showed widespread transcriptomic changes in gene expression and alternative splicing. They indicated that brainderived neurotrophic factor deficiency has a potential role in developmental delay, hyperphagia, and obesity in PWS. ${ }^{51-53)}$

Compared to simple obesity, PWS patients have less lean body mass and more fat mass, mainly distributed in the trunk, and less visceral obesity. ${ }^{5455)}$ These findings indicate that reduced resting energy expenditure (REE) might promote obesity in PWS patients. ${ }^{22)}$ Some studies have hypothesized that altered gene expression in the mitochondria play a role in the reduction in energy metabolism observed in PWS. ${ }^{56,57)}$

Considered together, hyperphagia and obesity in PWS are thought to be caused by complex mechanisms of hypothalamic dysfunction, hormonal circuits involved in appetite or satiety control, changes in body composition, and decreased REE.

\section{Management of hyperphagia and obesity in PWS}

Obesity control is the most important goal in PWS treatment. However, this task is difficult due to patient decreased lean body mass, reduced REE, and behavioral problems related to appetite control. Early dietary intervention and nutritional counseling are critical in preventing excessive weight gain and development of morbid obesity. The first months of life require dietary treatment for adequate nutrition to prevent malnutrition and failure to thrive. Exercise, behavioral modifications, and a balanced, low-calorie diet can prevent obesity and its complications. Schmidt et al. ${ }^{58)}$ reported that early dietary treatment with strict fat reduction beginning at

Table 1. anorexigenic or adipose-derives hormones in Prader-Willi syndrome (PWS)

\begin{tabular}{|c|c|c|c|c|c|}
\hline Hormone & Site of production & Site of action & Physiological role & Patients with PWS & References \\
\hline Obestatin & $\begin{array}{l}\text { Stomach, derived from } \\
\text { preproghrelin }\end{array}$ & AgRP in arcuate nucleus & $\begin{array}{l}\text { Appetite } \downarrow \\
\text { Gastric emptying } \downarrow \\
\text { Body weight } \downarrow\end{array}$ & $\begin{array}{l}\text { Contradictory results } \\
\text { Higher in young }(<3 \mathrm{yr}) \text { PWS } \\
\text { infants } \\
\text { No difference between obese } \\
\text { PWS and obese control }\end{array}$ & $43,45,48$ \\
\hline Adiponectin & Adipose tissue & $\beta$-cell in pancreas & $\begin{array}{l}\text { Insulin sensitivity } \uparrow \\
\text { Modulate appetite and } \\
\text { energy homeostasis }\end{array}$ & $\begin{array}{l}\text { Higher in PWS than obese } \\
\text { control }\end{array}$ & $42,44,46$ \\
\hline $\begin{array}{l}\text { Pancreatic polypeptide } \\
\text { (PP) }\end{array}$ & PP cell in pancreas & $\begin{array}{l}\text { Y4 receptors in hypothalamic } \\
\text { feeding nuclei }\end{array}$ & $\begin{array}{l}\text { Appetite } \downarrow \\
\text { Regulate pancreatic } \\
\text { secretion }\end{array}$ & $\begin{array}{l}\text { Similar or lower in PWS than } \\
\text { control } \\
\text { Decreased postprandial level } \\
\text { in PWS }\end{array}$ & 47 \\
\hline Peptide YY & Gastrointestinal tract & NPY receptor & $\begin{array}{l}\text { Appetite } \downarrow \\
\text { Gastric motility } \downarrow \\
\text { Pancreatic secretion } \downarrow\end{array}$ & Contradictory results & 41,47 \\
\hline Adropin & Liver, brain & Multiorgan & $\begin{array}{l}\text { Insulin sensitivity } \uparrow \\
\text { Body weight, fat mass } \downarrow\end{array}$ & Higher in PWS children & 48 \\
\hline Glucagon like peptide-1 & Intestine & Pancreas & $\begin{array}{l}\text { Insulin sensitivity } \uparrow \\
\text { Satiety } \uparrow\end{array}$ & $\begin{array}{l}\text { No difference between PWS } \\
\text { and control }\end{array}$ & 46 \\
\hline Leptin & Adipose tissue & $\begin{array}{l}\text { POMC and NPY in arcuate } \\
\text { nucleus }\end{array}$ & Satiety $\uparrow$ & $\begin{array}{l}\text { No difference between obese } \\
\text { PWS and obese control }\end{array}$ & $46,47,49$ \\
\hline
\end{tabular}

AgRP, agouti-related peptide; NPY, neuropeptide Y; POMC, proopiomelanocortin. 
the age of 2 years was effective in preventing excessive weight gain after 10 years of age. Infants and children with PWS should consume $60 \%-80 \%$ of the recommended daily allowance to maintain their body weight due to a reduced REE. ${ }^{15,17,59)}$ Because some children with PWS also exhibit food-seeking and foodstealing behaviors, strategies such as environmental barriers to food access (locking the kitchen, refrigerator, or cupboards) and restricting access to money and food are needed. ${ }^{60)}$

To date, pharmacologic treatment of hyperphagia and obesity in PWS has been limited. From the 1990s to the early 2010s, drugs of various mechanisms have been tested to control appetite and obesity in PWS patients, including beta endorphin antagonists (such as naltrexone), pancreatic lipase inhibitors (such as orlistat), insulin sensitizers (such as metformin), nonspecific inhibitors of serotonin and norepinephrine (including sibutramine), $\mathrm{Na}+$ channel/gamma-aminobutyric acid modulators (topiramate), and endocannabinoid 1 receptor antagonists (rimonabant, etc.). ${ }^{60,61)}$ However, no drugs have been proven effective, and some have been withdrawn from the market due to side effects. Early initiation and long-term use of growth hormone $(\mathrm{GH})$ treatment increases muscle mass and reduces body mass index (BMI) in these patients but is ineffective at controlling appetite or food-seeking behavior. Furthermore, most PWS patients who have been treated with GH remain obese. ${ }^{62)}$

Bariatric surgery is rarely performed in PWS patients because they are at high risk for gastric necrosis or rupture due to delayed gastric emptying and a decreased sensation of fullness. ${ }^{60,63)}$

\section{Clinical trials of hyperphagia and obesity in PWS}

Several ongoing or completed randomized controlled trials (RCTs) for treatment of hyperphagia and obesity in PWS have included a glucagon-like peptide-1 agonist, a melanocortin 4 receptor (MC4R) agonist, diazoxide, oxytocin/carbetocin, UAG analog (AZP-531), etc.

Some case reports and clinical trials have reported that treatment with a GLP-1 agonist, such as exenatide or liraglutide, had beneficial effects on obesity, satiety, and glycemic control in PWS patients. ${ }^{64-66)}$ Fintini et al. ${ }^{67)}$ reported that 24 months of subcutaneous liraglutide treatment showed a tendency to decrease BMI, glycosylated hemoglobin (HbAlc), and waist circumference in six obese PWS adults with T2DM, and it was well-tolerated. Salehi et al. ${ }^{64)}$ found that six months of exenatide treatment decreased the appetite scores and HbAlc level in 10 obese PWS adolescents, but weight, BMI, adiposity, and ghrelin did not change. Large-scale, randomized-controlled, longterm studies on the effects and safety of GLP-1 agonists are needed. No GLP-1 agonist has been approved for children and adolescents in Korea.

Setmelanotide, an MC4R agonist also known as RM-493, is a synthetic peptide that binds strongly to human MC4R. Its side effects include headache, arthralgia, or skin darkening. It has no effects on heart rate or blood pressure and has been shown to increase REE and fat oxidation in obese individuals. However, a phase $2 \mathrm{a}$ trial in obese PWS patients (ClinicalTrials.gov: NCT02311673) showed only modest changes in hyperphagia without any reduction in body weight. ${ }^{60)}$

Diazoxide is a potent $\mathrm{K}+$-ATP channel agonist with a wellcharacterized safety profile. Diazoxide choline controlledrelease (DCCR) is hypothesized to reduce the synthesis and secretion of appetite stimulatory neuropeptides in the arcuate neuron, thereby reducing hyperphagia in PWS. In a phase 2 study, DCCR reduced appetite and aggressive behaviors, improved insulin sensitivity, and decreased waist circumference and fat mass in PWS adults. ${ }^{68)}$ A multicenter phase 3 clinical trial (ClinicalTrials.gov: NCT03440814) with DCCR for PWS is underway.

As previously mentioned, abnormalities in the oxytocin system are thought to play some role in appetite control and behavioral problems in PWS. ${ }^{32-35)}$ Several RCTs using oxytocin or its analog (intranasal carbetocin) have been conducted in PWS patients. No evidence suggests that intranasal oxytocin improves symptoms and hyperphagia in PWS. ${ }^{39,69,70)}$ However, improvements in oral feeding skills have been observed in very young PWS infants who received a short course of oxytocin within the first 6 months of life. ${ }^{71)}$ A recently completed RCT (ClinicalTrials.gov: NCT01968187) reported intranasal carbetocin was well-tolerated and improved hyperphagia and behavioral symptoms in PWS patients. ${ }^{72)}$

Ghrelin exhibits unique concentration changes in PWS and might be a pharmacotherapeutic target for these patients. In a phase 2 RCT, a daily subcutaneous injection of a UAG analogue (AZP-531) improved the appetite score, waist circumference, and fat mass in 47 PWS patients. ${ }^{40)}$ In addition, a phase 2 RCT (ClinicalTrials.gov: NCT03274856) using GLWL-01, a ghrelin $\mathrm{O}$-acyltransferase inhibitor that blocks the conversion of ghrelin to AG, was recently completed in PWS patients, and the results are awaiting analysis. Drugs that affect the ghrelin system could be new treatment options for ameliorating hyperphagia in PWS patients if the effect is consistently demonstrated in large-scale, long-term follow-up studies.

Although no drug yet has shown consistent efficacy in hyperphagia and obesity in PWS, the results of completed or ongoing RCTs deserve attention.

\section{Endocrine problems in PWS}

\section{Growth hormone deficiency}

GHD is the most commonly reported endocrine problem that occurs in $40 \%-100 \%$ of PWS patients. The exact mechanism of GHD is unclear. PWS is associated with reduced 24-hour GH secretion, insufficient response to GH stimulation tests, and a decreased serum IGF-1 concentration. ${ }^{23,73,74)}$ Children diagnosed with PWS should receive GH treatment (GHT) without GH stimulation tests by as early as 3 to 6 
months of age. ${ }^{73,75)}$ GHT in children with PWS increases their final height and compensates for metabolic disorders caused by GHD. Some studies have reported that early GHT improves motor and cognitive development, socialization, and body composition. ${ }^{75-77)}$ In Korea, GHT is currently covered by the national health insurance for children over 2 years of age who have been diagnosed with PWS. Given the recent trend toward PWS diagnoses in younger children, allowing infants to receive GHT should be considered.

GHT has growth and metabolic benefits and is relatively safe and well-tolerated in children and adolescents with PWS. Therefore, this population should receive GHT until the end of their linear growth period. Based on the benefits of GHT in PWS, some suggest that it be continued in adulthood or offered to previously untreated adults with PWS. ${ }^{78)}$

Recent studies have demonstrated that GHT cessation led to a deteriorated physical and social status and increases in visceral fat, low-density lipoprotein cholesterol, and total cholesterol levels in young adult PWS patients. ${ }^{7980)}$ In 2020, Damen et $\mathrm{al}^{81)}$ reported that continued GHT in young adults with PWS maintains the positive effects on body composition attained during childhood. However, since not all adults with PWS meet the diagnostic criteria for GHD by GH stimulation tests, ${ }^{82)}$ an appropriate GH stimulation test method must be established. Further studies are needed to clarify the indications, benefits, and adverse effects of GHT in patients of a transitional age or adults with PWS.

\section{Hypothyroidism}

Hypothalamic dysfunction can be associated with central hypothyroidism; the prevalence of hypothyroidism in PWS patients ranges from $2 \%-4 \%$ to $20 \%-30 \%{ }^{83-85)}$ Vaiani et al. ${ }^{86)}$ reported that $72 \%$ of PWS infants showed low free T4 level and transient or definite thyroid axis dysfunction during their first 2 years of life. Several clinical guidelines recommend that thyroid function be evaluated at the time of the PWS diagnosis and then again annually, especially during GHT. These cases should be treated with levothyroxine immediately if hypothyroidism is present. $^{15,17,85)}$

\section{Central adrenal insufficiency}

The prevalence of CAI in PWS patients has been reported to be $0 \%-60 \%{ }^{87-90)}$ Farholt et al. ${ }^{89)}$ revealed a normal cortisol response to high-dose adrenocorticotropic hormone (ACTH) and insulin-tolerance testing (ITT) in 65 children and adults with PWS. Corrias et al. ${ }^{90)}$ showed that $14.3 \%$ (12 of 84) of PWS children had a pathological cortisol peak response to the lowdose ACTH stimulation test. de Lind van Wijngaarden et al. ${ }^{87)}$ found that $60 \%$ of patients with PWS demonstrated a low peak ACTH response on the metyrapone test and met the diagnostic criteria for CAI. In addition, Oto et al. ${ }^{91)}$ reported that a peak response of cortisol to ITT was delayed in 64\% (23 of 36) of
PWS patients, which complicated diagnosis of CAI in PWS. Although clinically distinct CAI patients are rare in PWS, the possibility of latent adrenal insufficiency cannot be excluded, as PWS patients with hypothalamic dysfunction are at risk for CAI. Muscogiuri et al. ${ }^{92)}$ recommended an evaluation of adrenal function before major surgery or anesthesia and use of glucocorticoids if severe hypotension develops during surgery in patients whose normal adrenal function is unconfirmed. However, in patients with CAI unconfirmed by hormone tests and clinical manifestations, chronic hydrocortisone supplementation is not necessary given its negative effects on bone mineral density, obesity, and glucose metabolism. ${ }^{10,92,93)}$

\section{Hypogonadism}

Hypogonadism is a typical clinical feature of PWS patients regardless of sex and age and is a combination of hypogonadotropic hypogonadism and primary gonadal failure. PWS patients normally go through a mini puberty. Although there are individual differences in the onset of puberty, this event occurs in a relatively typical age range. ${ }^{10,92)}$ With the onset of puberty, the concentrations of sex hormones (testosterone and estradiol) increase but remain lower than the normal ranges. The serum levels of luteinizing hormone, follicle stimulating hormone, and inhibin B can vary due to the mixed nature of hypogonadism. Therefore, the clinical presentation of hypogonadism in PWS patients is highly variable.

In male PWS patients, cryptorchidism (unilateral or bilateral) is very common and is reported in $66 \%-100 \%$ of newborns; most require orchiopexy. ${ }^{92,94)}$ Male PWS patients often have thick suprapubic fat pads and a smaller penis size than healthy individuals. This condition is more severe in obese patients and sometimes makes it difficult to urinate while standing. ${ }^{10)}$ Most male PWS patients begin puberty at a normal age range, but early or delayed puberty has also been reported. However, the progression of puberty usually arrests at Tanner stage III, and testicular size is smaller than that of a normal adult male. Men with PWS are thought to be infertile, and no cases of a male with PWS fathering children have been reported. ${ }^{93)}$ To date, hypogonadism management guidelines for PWS patients have not been established. Negative effects on skeletal maturation and behavioral problems must be considered when attempting testosterone replacement treatment for a male with PWS. 3 .10,15,17,92)

Hypoplasia of the labia majora and clitoris at birth is noted in $76 \%$ of females with PWS. ${ }^{94)}$ Puberty in females with PWS begins at a normal age but is delayed in Tanner stages III-IV; $8 \%-25 \%$ of these patients experience spontaneous periods. The average age at menarche is delayed to 20 years. ${ }^{95)}$ Although most females with PWS have subsequent oligomenorrhea or secondary amenorrhea after menarche, they can become reproductive. Six pregnancies have been reported in women with PWS. ${ }^{10)}$ Angelman syndrome can occur if a PWS patient with a 15q11.2-q13 deletion gives birth to a child, so education 
Table 2. Recommendations for endocrinologic problems in Prader-Willi syndrome (PWS)

\begin{tabular}{|c|c|c|c|}
\hline Endocrine problems & Age of life & Screening and monitoring & Managements \\
\hline \multirow[t]{3}{*}{ Growth hormone deficiency } & Early infancy & $\begin{array}{l}\text { Monitoring of growth according to disease-specific } \\
\text { growth curve }\end{array}$ & $\begin{array}{l}\text { GHT start as diagnosis of PWS is made (as early as } \\
3-6 \text { months of age) }\end{array}$ \\
\hline & $\begin{array}{l}\text { Childhood and } \\
\text { adolescence }\end{array}$ & $\begin{array}{l}\text { Monitoring of growth, skeletal maturation, puberal } \\
\text { development. } \\
\text { If sleep apnea is developed, adenoid assessment } \\
\text { and polysomnography are needed. } \\
\text { Regular assessment of anthropometric measure, } \\
\text { IGF-1,TFT, glucose metabolism, scoliosis }\end{array}$ & $\begin{array}{l}\text { GHT start as soon as possible after PWS diagnosis } \\
\text { or continue GHT with monitoring }\end{array}$ \\
\hline & Adulthood & $\begin{array}{l}\text { Assessment of IGF-1, lipid and glucose metabolism, } \\
\text { BMI, lean body mass }\end{array}$ & $\begin{array}{l}\text { Considering restart GHT with confirmed GHD after } \\
\text { achievement of final height }\end{array}$ \\
\hline \multirow[t]{2}{*}{ Hypothyroidism } & Early infancy & TFT within first 3 months of age & $\begin{array}{l}\text { Levothyroxine supplement at typical replacement } \\
\text { dose }\end{array}$ \\
\hline & After childhood & TFT annually, or every 6 months during GHT & \\
\hline Central adrenal insufficiency & All age & $\begin{array}{l}\text { Educate patients and their families on signs and } \\
\text { symptoms of adrenal insufficiency } \\
\text { Consider adrenal function test at presenting } \\
\text { clinical features or prior to major surgery or } \\
\text { anesthesia }\end{array}$ & $\begin{array}{l}\text { Hydrocortisone supplement at typical replacement } \\
\text { dose }\end{array}$ \\
\hline \multirow[t]{3}{*}{ Hypogonadism } & $\begin{array}{l}\text { Newborn and } \\
\text { early infancy }\end{array}$ & Examination for cryptorchidism in male & Orchiopexy in most case \\
\hline & $\begin{array}{l}\text { Childhood and } \\
\text { adolescence }\end{array}$ & $\begin{array}{l}\text { Monitoring of pubertal initiation and progression } \\
\text { Assessment of LH, FHS, testosterone/estradiol, } \\
\text { inhibin B }\end{array}$ & $\begin{array}{l}\text { If delayed or stalled puberty, consider sex } \\
\text {, hormones replacement therapy }\end{array}$ \\
\hline & Adulthood & $\begin{array}{l}\text { Assessment of LH, FHS, testosterone/estradiol, } \\
\text { inhibin B }\end{array}$ & $\begin{array}{l}\text { Consider sex hormones replacement therapy } \\
\text { Counsel for contraception in female }\end{array}$ \\
\hline
\end{tabular}

GHT, growth hormone treatment; IGF-1, insulin like growth factor-1; BMI, body mass index; TFT, thyroid function test.

and genetic counseling is required for all female patients with PWS ${ }^{96)}$ Although there is no consensus on the utility of hormone replacement therapy in this population, treatment should consider the potentially positive effects on bone density and body image and also the negative effects on skeletal maturation. ${ }^{3,10,15,17)}$

The prevalence of premature adrenarche has been reported in up to $30 \%$ of PWS patients. Premature adrenarche is associated with pubic/axillary hair, advanced bone age, and increased serum dehydroepiandrosterone sulfate level. This condition is generally considered benign, and further tests or treatment are typically not required. ${ }^{9,9293)}$

\section{Conclusion}

PWS is a complex genetic disorder characterized by uncontrolled appetite, severe obesity, and multiple endocrine problems. Understanding the mechanisms that lead to hyperphagia and obesity in PWS is critical to understanding and managing patients with PWS. So far, early intensive nutritional therapy with behavioral modifications is the best method to control appetite and obesity in PWS. However, several clinical trials investigating appetite suppression and obesity control are ongoing. We hope to attempt pharmacotherapy in the near future to address these issues. Proper management of PWS patients requires a multidisciplinary team approach. It is important for pediatric endocrinologists to be aware of the recommendations for screening and monitoring of various endocrine problems that can occur in PWS (Table 2).

\section{Conflicts of interest}

No potential conflict of interest relevant to this article was reported.

\section{Funding}

This research received no specific grant from any funding agency in the public, commercial, or not-for-profit sectors.

\section{References}

1. Cassidy SB, Schwartz S, Miller JL, Driscoll DJ. Prader-Willi syndrome. Genet Med 2012;14:10-26.

2. Cheon CK. Genetics of Prader-Willi syndrome and PraderWill-Like syndrome. Ann Pediatr Endocrinol Metab 2016;21:126-35.

3. Butler MG, Miller JL, Forster JL. Prader-Willi syndrome clinical genetics, diagnosis and treatment approaches: an update. Curr Pediatr Rev 2019;15:207-44.

4. Irizarry KA, Miller M, Freemark M, Haqq AM. Prader Willi syndrome: genetics, metabolomics, hormonal function, and new approaches to therapy. Adv Pediatr 2016;63:47-77.

5. Rocha CF, Paiva CL. Prader-Willi-like phenotypes: a systematic review of their chromosomal abnormalities. Genet Mol Res 2014;13:2290-8. 
6. Angulo MA, Butler MG, Cataletto ME. Prader-Willi syndrome: a review of clinical, genetic, and endocrine findings. J Endocrinol Invest 2015;38:1249-63.

7. Driscoll DJ, Miller JL, Schwartz S, Cassidy SB. Prader-Willi syndrome. In: Adam MP, Ardinger HH, Pagon RA, Wallace SE, Bean LJH, Mirzaa G, et al., editors. GeneReviews ${ }^{\circ}$ [Internet]. Seattle (WA): University of Washington, Seattle; 1993-2021.

8. Bar C, Diene G, Molinas C, Bieth E, Casper C, Tauber M. Early diagnosis and care is achieved but should be improved in infants with Prader-Willi syndrome. Orphanet J Rare Dis 2017;12:118.

9. Harris RM, Stafford DEJ. Prader Willi syndrome: endocrine updates and new medical therapies. Curr Opin Endocrinol Diabetes Obes 2020;27:56-62.

10. Heksch R, Kamboj M, Anglin K, Obrynba K. Review of Prader-Willi syndrome: the endocrine approach. Transl Pediatr 2017;6:274-85.

11. Miller JL, Lynn CH, Driscoll DC, Goldstone AP, Gold JA, Kimonis V, et al. Nutritional phases in Prader-Willi syndrome. Am J Med Genet A 2011;155A:1040-9.

12. Gross N, Rabinowitz R, Gross-Tsur V, Hirsch HJ, EldarGeva T. Prader-Willi syndrome can be diagnosed prenatally. Am J Med Genet A 2015;167A:80-5.

13. Lee J, Isojima T, Chang MS, Kwun YH, Huh R, Cho SY, et al. Disease-specific growth charts for Korean infants with Prader-Willi syndrome. Am J Med Genet A 2015;167A:8694.

14. Rosenbloom ST, Butler MG. Development and implementation of electronic growth charts for infants with Prader-Willi syndrome. Am J Med Genet A 2012;158A:2743-9.

15. Goldstone AP, Holland AJ, Hauffa BP, Hokken-Koelega AC, Tauber M; speakers contributors at the Second Expert Meeting of the Comprehensive Care of Patients with PWS. Recommendations for the diagnosis and management of Prader-Willi syndrome. J Clin Endocrinol Metab 2008;93:4183-97.

16. Cassidy SB, Driscoll DJ. Prader-Willi syndrome. Eur J Hum Genet 2009;17:3-13.

17. McCandless SE, Committee on G. Clinical report-health supervision for children with Prader-Willi syndrome. Pediatrics 2011;127:195-204.

18. Whittington JE, Holland AJ, Webb T, Butler J, Clarke D, Boer $\mathrm{H}$. Population prevalence and estimated birth incidence and mortality rate for people with Prader-Willi syndrome in one UK Health Region. J Med Genet 2001;38:792-8.

19. Butler MG, Manzardo AM, Heinemann J, Loker C, Loker J. Causes of death in Prader-Willi syndrome: Prader-Willi Syndrome Association (USA) 40-year mortality survey. Genet Med 2017;19:635-42.

20. Pacoricona Alfaro DL, Lemoine P, Ehlinger V, Molinas C, Diene G, Valette M, et al. Causes of death in Prader-Willi syndrome: lessons from 11 years' experience of a national reference center. Orphanet J Rare Dis 2019;14:238.

21. Lionti T, Reid SM, Rowell MM. Prader-Willi syndrome in
Victoria: mortality and causes of death. J Paediatr Child Health 2012;48:506-11.

22. Butler MG, Theodoro MF, Bittel DC, Donnelly JE. Energy expenditure and physical activity in Prader-Willi syndrome: comparison with obese subjects. Am J Med Genet A 2007;143A:449-59.

23. Burman P, Ritzen EM, Lindgren AC. Endocrine dysfunction in Prader-Willi syndrome: a review with special reference to GH. Endocr Rev 2001;22:787-99.

24. Khan MJ, Gerasimidis K, Edwards CA, Shaikh MG. Mechanisms of obesity in Prader-Willi syndrome. Pediatr Obes 2018;13:3-13.

25. Holsen LM, Savage CR, Martin LE, Bruce AS, Lepping RJ, Ko E, et al. Importance of reward and prefrontal circuitry in hunger and satiety: Prader-Willi syndrome vs simple obesity. Int J Obes (Lond) 2012;36:638-47.

26. Blanco-Hinojo L, Pujol J, Esteba-Castillo S, MartinezVilavella G, Gimenez-Palop O, Gabau E, et al. Lack of response to disgusting food in the hypothalamus and related structures in Prader Willi syndrome. Neuroimage Clin 2019;21:101662.

27. Dimitropoulos A, Schultz RT. Food-related neural circuitry in Prader-Willi syndrome: response to high- versus lowcalorie foods. J Autism Dev Disord 2008;38:1642-53.

28. DelParigi A, Tschop M, Heiman ML, Salbe AD, Vozarova B, Sell SM, et al. High circulating ghrelin: a potential cause for hyperphagia and obesity in prader-willi syndrome. J Clin Endocrinol Metab 2002;87:5461-4.

29. Haqq AM, Farooqi IS, O'Rahilly S, Stadler DD, Rosenfeld RG, Pratt KL, et al. Serum ghrelin levels are inversely correlated with body mass index, age, and insulin concentrations in normal children and are markedly increased in Prader-Willi syndrome. J Clin Endocrinol Metab 2003;88:174-8.

30. Kweh FA, Miller JL, Sulsona CR, Wasserfall C, Atkinson M, Shuster JJ, et al. Hyperghrelinemia in Prader-Willi syndrome begins in early infancy long before the onset of hyperphagia. Am J Med Genet A 2015;167A:69-79.

31. Beauloye V, Diene G, Kuppens R, Zech F, Winandy C, Molinas C, et al. High unacylated ghrelin levels support the concept of anorexia in infants with prader-willi syndrome. Orphanet J Rare Dis 2016;11:56.

32. Lawson EA, Olszewski PK, Weller A, Blevins JE. The role of oxytocin in regulation of appetitive behaviour, body weight and glucose homeostasis. J Neuroendocrinol 2020;32:e12805.

33. Swaab DF, Purba JS, Hofman MA. Alterations in the hypothalamic paraventricular nucleus and its oxytocin neurons (putative satiety cells) in Prader-Willi syndrome: a study of five cases. J Clin Endocrinol Metab 1995;80:573-9.

34. Martin A, State M, Anderson GM, Kaye WM, Hanchett JM, McConaha CW, et al. Cerebrospinal fluid levels of oxytocin in Prader-Willi syndrome: a preliminary report. Biol Psychiatry 1998;44:1349-52.

35. Johnson L, Manzardo AM, Miller JL, Driscoll DJ, Butler MG. Elevated plasma oxytocin levels in children with 
Prader-Willi syndrome compared with healthy unrelated siblings. Am J Med Genet A 2016;170:594-601.

36. Xue Q, Bai B, Ji B, Chen X, Wang C, Wang P, et al. Ghrelin through GHSR1a and OX1R heterodimers reveals a Galphas-cAMP-cAMP response element binding protein signaling pathway in vitro. Front Mol Neurosci 2018;11:245.

37. Wallace Fitzsimons SE, Chruscicka B, Druelle C, Stamou P, Nally K, Dinan TG, et al. A ghrelin receptor and oxytocin receptor heterocomplex impairs oxytocin mediated signalling. Neuropharmacology 2019;152:90-101.

38. Kuppens RJ, Donze SH, Hokken-Koelega AC. Promising effects of oxytocin on social and food-related behaviour in young children with Prader-Willi syndrome: a randomized, double-blind, controlled crossover trial. Clin Endocrinol (Oxf) 2016;85:979-87.

39. Miller JL, Tamura R, Butler MG, Kimonis V, Sulsona C, Gold JA, et al. Oxytocin treatment in children with PraderWilli syndrome: a double-blind, placebo-controlled, crossover study. Am J Med Genet A 2017;173:1243-50.

40. Allas S, Caixas A, Poitou C, Coupaye M, Thuilleaux D, Lorenzini F, et al. AZP-531, an unacylated ghrelin analog, improves food-related behavior in patients with PraderWilli syndrome: a randomized placebo-controlled trial. PLoS One 2018;13:e0190849.

41. Butler MG, Bittel DC, Talebizadeh Z. Plasma peptide YY and ghrelin levels in infants and children with Prader-Willi syndrome. J Pediatr Endocrinol Metab 2004;17:1 177-84.

42. Hoybye C, Bruun JM, Richelsen B, Flyvbjerg A, Frystyk J. Serum adiponectin levels in adults with Prader-Willi syndrome are independent of anthropometrical parameters and do not change with GH treatment. Eur J Endocrinol 2004;151:457-61.

43. Butler MG, Bittel DC. Plasma obestatin and ghrelin levels in subjects with Prader-Willi syndrome. Am J Med Genet A 2007;143A:415-21.

44. Haqq AM, Muehlbauer M, Svetkey LP, Newgard CB, Purnell JQ, Grambow SC, et al. Altered distribution of adiponectin isoforms in children with Prader-Willi syndrome (PWS): association with insulin sensitivity and circulating satiety peptide hormones. Clin Endocrinol (Oxf) 2007;67:944-51.

45. Park WH, Oh YJ, Kim GY, Kim SE, Paik KH, Han SJ, et al. Obestatin is not elevated or correlated with insulin in children with Prader-Willi syndrome. J Clin Endocrinol Metab 2007;92:229-34.

46. Haqq AM, Muehlbauer MJ, Newgard CB, Grambow $S$, Freemark M. The metabolic phenotype of PraderWilli syndrome (PWS) in childhood: heightened insulin sensitivity relative to body mass index. J Clin Endocrinol Metab 2011;96:E225-32.

47. Goldstone AP, Holland AJ, Butler JV, Whittington JE. Appetite hormones and the transition to hyperphagia in children with Prader-Willi syndrome. Int J Obes (Lond) 2012;36:1564-70.

48. Orsso CE, Butler AA, Muehlbauer MJ, Cui HN, Rubin DA, Pakseresht M, et al. Obestatin and adropin in PraderWilli syndrome and nonsyndromic obesity: associations with weight, BMI-z, and HOMA-IR. Pediatr Obes 2019;14:e12493.

49. Butler MG, Moore J, Morawiecki A, Nicolson M. Comparison of leptin protein levels in Prader-Willi syndrome and control individuals. Am J Med Genet 1998;75:7-12.

50. Bochukova EG. Transcriptomics of the PraderWilli syndrome hypothalamus. Handb Clin Neurol 2021;181:369-79.

51. Bochukova EG, Lawler K, Croizier S, Keogh JM, Patel $\mathrm{N}$, Strohbehn G, et al. A transcriptomic signature of the hypothalamic response to fasting and BDNF deficiency in Prader-Willi syndrome. Cell Rep 2018;22:3401-8.

52. Gray J, Yeo GS, Cox JJ, Morton J, Adlam AL, Keogh JM, et al. Hyperphagia, severe obesity, impaired cognitive function, and hyperactivity associated with functional loss of one copy of the brain-derived neurotrophic factor (BDNF) gene. Diabetes 2006;55:3366-71.

53. Han JC, Muehlbauer MJ, Cui HN, Newgard CB, Haqq AM. Lower brain-derived neurotrophic factor in patients with prader-willi syndrome compared to obese and lean control subjects. J Clin Endocrinol Metab 2010;95:3532-6.

54. Lloret-Linares C, Faucher P, Coupaye M, Alili R, Green A, Basdevant A, et al. Comparison of body composition, basal metabolic rate and metabolic outcomes of adults with Prader Willi syndrome or lesional hypothalamic disease, with primary obesity. Int J Obes (Lond) 2013;37:1198-203.

55. Lacroix D, Moutel S, Coupaye M, Huvenne H, Faucher P, Pelloux V, et al. Metabolic and adipose tissue signatures in adults with Prader-Willi syndrome: a model of extreme adiposity. J Clin Endocrinol Metab 2015;100:850-9.

56. Yazdi PG, Su H, Ghimbovschi S, Fan W, Coskun PE, Nalbandian A, et al. Differential gene expression reveals mitochondrial dysfunction in an imprinting center deletion mouse model of Prader-Willi syndrome. Clin Transl Sci 2013;6:347-55.

57. Butler MG, Hossain WA, Tessman R, Krishnamurthy PC. Preliminary observations of mitochondrial dysfunction in Prader-Willi syndrome. Am J Med Genet A 2018;176:258794.

58. Schmidt H, Pozza SB, Bonfig W, Schwarz HP, Dokoupil K. Successful early dietary intervention avoids obesity in patients with Prader-Willi syndrome: a ten-year follow-up. J Pediatr Endocrinol Metab 2008;21:651-5.

59. Miller JL. Approach to the child with prader-willi syndrome. J Clin Endocrinol Metab 2012;97:3837-44.

60. Crino A, Fintini D, Bocchini S, Grugni G. Obesity management in Prader-Willi syndrome: current perspectives. Diabetes Metab Syndr Obes 2018;11:579-93.

61. Griggs JL, Sinnayah P, Mathai ML. Prader-Willi syndrome: From genetics to behaviour, with special focus on appetite treatments. Neurosci Biobehav Rev 2015;59:155-72.

62. Sipila I, Sintonen H, Hietanen H, Apajasalo M, Alanne S, Viita AM, et al. Long-term effects of growth hormone therapy on patients with Prader-Willi syndrome. Acta Paediatr 2010;99:1712-8. 
63. Scheimann AO, Butler MG, Gourash L, Cuffari C, Klish W. Critical analysis of bariatric procedures in Prader-Willi syndrome. J Pediatr Gastroenterol Nutr 2008;46:80-3.

64. Salehi P, Hsu I, Azen CG, Mittelman SD, Geffner ME, Jeandron D. Effects of exenatide on weight and appetite in overweight adolescents and young adults with Prader-Willi syndrome. Pediatr Obes 2017;12:221-8.

65. Kim YM, Lee YJ, Kim SY, Cheon CK, Lim HH. Successful rapid weight reduction and the use of liraglutide for morbid obesity in adolescent Prader-Willi syndrome. Ann Pediatr Endocrinol Metab 2020;25:52-6.

66. Senda M, Ogawa S, Nako K, Okamura M, Sakamoto T, Ito S. The glucagon-like peptide-1 analog liraglutide suppresses ghrelin and controls diabetes in a patient with Prader-Willi syndrome. Endocr J 2012;59:889-94.

67. Fintini D, Grugni G, Brufani C, Bocchini S, Cappa M, Crino A. Use of GLP-1 receptor agonists in Prader-Willi Syndrome: report of six cases. Diabetes Care 2014;37:e76-7.

68. Kimonis V, Surampalli A, Wencel M, Gold JA, Cowen NM. A randomized pilot efficacy and safety trial of diazoxide choline controlled-release in patients with Prader-Willi syndrome. PLoS One 2019;14:e0221615.

69. Einfeld SL, Smith E, McGregor IS, Steinbeck K, Taffe J, Rice LJ, et al. A double-blind randomized controlled trial of oxytocin nasal spray in Prader Willi syndrome. Am J Med Genet A 2014;164A:2232-9.

70. Hollander E, Levine KG, Ferretti CJ, Freeman K, Doernberg $\mathrm{E}$, Desilva N, et al. Intranasal oxytocin versus placebo for hyperphagia and repetitive behaviors in children with Prader-Willi Syndrome: a randomized controlled pilot trial. J Psychiatr Res 2021;137:643-51.

71. Tauber M, Boulanouar K, Diene G, Çabal-Berthoumieu S, Ehlinger V, Fichaux-Bourin P, et al. The use of oxytocin to improve feeding and social skills in infants with PraderWilli syndrome. Pediatrics 2017;139:e20162976.

72. Dykens EM, Miller J, Angulo M, Roof E, Reidy M, Hatoum HT, et al. Intranasal carbetocin reduces hyperphagia in individuals with Prader-Willi syndrome. JCI Insight 2018;3:e98333.

73. Bridges $\mathrm{N}$. What is the value of growth hormone therapy in Prader Willi syndrome? Arch Dis Child 2014;99:166-70.

74. Cohen M, Harrington J, Narang I, Hamilton J. Growth hormone secretion decreases with age in paediatric PraderWilli syndrome. Clin Endocrinol (Oxf) 2015;83:212-5.

75. Carrel AL, Myers SE, Whitman BY, Eickhoff J, Allen DB. Long-term growth hormone therapy changes the natural history of body composition and motor function in children with Prader-Willi syndrome. J Clin Endocrinol Metab 2010;95:1131-6.

76. Myers SE, Whitman BY, Carrel AL, Moerchen V, Bekx MT, Allen DB. Two years of growth hormone therapy in young children with Prader-Willi syndrome: physical and neurodevelopmental benefits. Am J Med Genet A 2007;143A:443-8.

77. Donze SH, Damen L, Mahabier EF, Hokken-Koelega ACS. Improved mental and motor development during 3 years of GH treatment in very young children with Prader-Willi syndrome. J Clin Endocrinol Metab 2018;103:3714-9.

78. Grugni G, Marzullo P. Diagnosis and treatment of GH deficiency in Prader-Willi syndrome. Best Pract Res Clin Endocrinol Metab 2016;30:785-94.

79. Koizumi M, Ida S, Shoji Y, Nishimoto Y, Etani Y, Kawai M. Visceral adipose tissue increases shortly after the cessation of GH therapy in adults with Prader-Willi syndrome. Endocr J 2018;65:1127-37.

80. Hoybye C, Thoren M, Bohm B. Cognitive, emotional, physical and social effects of growth hormone treatment in adults with Prader-Willi syndrome. J Intellect Disabil Res 2005;49(Pt 4):245-52.

81. Damen L, Donze SH, Kuppens RJ, Bakker NE, de Graaff LCG, van der Velden J, et al. Three years of growth hormone treatment in young adults with Prader-Willi syndrome: sustained positive effects on body composition. Orphanet J Rare Dis 2020;15:163.

82. Grugni G, Marzullo P, Ragusa L, Sartorio A, Trifiro G, Liuzzi $\mathrm{A}$, et al. Impairment of $\mathrm{GH}$ responsiveness to combined GH-releasing hormone and arginine administration in adult patients with Prader-Willi syndrome. Clin Endocrinol (Oxf) 2006;65:492-9.

83. Butler MG, Theodoro M, Skouse JD. Thyroid function studies in Prader-Willi syndrome. Am J Med Genet A 2007;143A:488-92.

84. Diene G, Mimoun E, Feigerlova E, Caula S, Molinas C, Grandjean H, et al. Endocrine disorders in children with Prader-Willi syndrome--data from 142 children of the French database. Horm Res Paediatr 2010;74:121-8.

85. Iughetti L, Vivi G, Balsamo A, Corrias A, Crino A, Delvecchio M, et al. Thyroid function in patients with Prader-Willi syndrome: an Italian multicenter study of 339 patients. J Pediatr Endocrinol Metab 2019;32:159-65.

86. Vaiani E, Herzovich V, Chaler E, Chertkoff L, Rivarola MA, Torrado M, et al. Thyroid axis dysfunction in patients with Prader-Willi syndrome during the first 2 years of life. Clin Endocrinol (Oxf) 2010;73:546-50.

87. de Lind van Wijngaarden RF, Otten BJ, Festen DA, Joosten KF, de Jong FH, Sweep FC, et al. High prevalence of central adrenal insufficiency in patients with Prader-Willi syndrome. J Clin Endocrinol Metab 2008;93:1649-54.

88. Grugni G, Beccaria L, Corrias A, Crino A, Cappa M, De Medici C, et al. Central adrenal insufficiency in young adults with Prader-Willi syndrome. Clin Endocrinol (Oxf) 2013;79:371-8.

89. Farholt S, Sode-Carlsen R, Christiansen JS, Ostergaard JR, Hoybye C. Normal cortisol response to high-dose synacthen and insulin tolerance test in children and adults with Prader-Willi syndrome. J Clin Endocrinol Metab 2011;96:E173-80.

90. Corrias A, Grugni G, Crino A, Di Candia S, Chiabotto P, Cogliardi A, et al. Assessment of central adrenal insufficiency in children and adolescents with Prader-Willi syndrome. Clin Endocrinol (Oxf) 2012;76:843-50.

91. Oto Y, Matsubara K, Ayabe T, Shiraishi M, Murakami N, 
Ihara $\mathrm{H}$, et al. Delayed peak response of cortisol to insulin tolerance test in patients with Prader-Willi syndrome. Am J Med Genet A 2018;176:1369-74.

92. Muscogiuri G, Formoso G, Pugliese G, Ruggeri RM, Scarano E, Colao A, et al. Prader- Willi syndrome: an uptodate on endocrine and metabolic complications. Rev Endocr Metab Disord 2019;20:239-50.

93. Tauber M, Hoybye C. Endocrine disorders in Prader-Willi syndrome: a model to understand and treat hypothalamic dysfunction. Lancet Diabetes Endocrinol 2021;9:235-46.
94. Crino A, Schiaffini R, Ciampalini P, Spera S, Beccaria L, Benzi F, et al. Hypogonadism and pubertal development in Prader-Willi syndrome. Eur J Pediatr 2003;162:327-33.

95. Eldar-Geva T, Hirsch HJ, Rabinowitz R, Benarroch F, Rubinstein O, Gross-Tsur V. Primary ovarian dysfunction contributes to the hypogonadism in women with PraderWilli Syndrome. Horm Res 2009;72:153-9.

96. Greco D, Vetri L, Ragusa L, Vinci M, Gloria A, Occhipinti P, et al. Prader-Willi syndrome with angelman syndrome in the offspring. Medicina (Kaunas) 2021;57:460. 